\title{
THE RELATIONSHIP BETWEEN HERITAGE PRODUCTS AND TOURISM IN THE DEVELOPMENT DOCUMENTS OF TOWNS IN HAJDÚ-BIHAR COUNTY
}

\author{
Bence MONYÓK \\ University of Debrecen, Faculty of Science and Technology, Department of Social Geography and Regional \\ Development Planning, Egyetem tér 1, 4032 Debrecen, Hungary, e-mail: bence.monyok@gmail.com
}

\section{Tibor KECSKÉS}

University of Debrecen, Faculty of Science and Technology, Department of Social Geography and Regional Development Planning, Egyetem tér 1, 4032 Debrecen, Hungary, e-mail: kecskestibor@freemail.hu

\section{Gábor KOZMA*}

University of Debrecen, Faculty of Science and Technology, Department of Social Geography and Regional Development Planning, Egyetem tér 1, 4032 Debrecen, Hungary, e-mail: kozma.gabor@science.unideb.hu

Citation: Monyók, B., Kecskés, T. \& Kozma, G. (2020). THE RELATIONSHIP BETWEEN HERITAGE PRODUCTS AND TOURISM IN THE DEVELOPMENT DOCUMENTS OF TOWNS IN HAJDÚ-BIHAR COUNTY. GeoJournal of Tourism and Geosites, 28(1), 257-267. https://doi.org/10.30892/gtg.28120-467

\begin{abstract}
Heritage tourism can be considered as one of the fastest developing branches of tourism today but the prerequisite of the success of local authorities in this filed is a proactive approach. In the spirit of the above, the aim of the present paper is to examine the development documents of the most important settlements of Hajdú-Bihar county (Hungary) and to answer the question how the heritage products appear in the specific documents concerned. As a result it can be concluded that firstly From among the values to be preserved in connection with heritage, the biggest emphasis is on the build environment; at the same time - due to the unique historical past of the towns - a very significant role is also given to the unique settlement structure. Secondly among the possible areas of the utilisation of heritage, the first place is occupied by the physical appearance of the settlements (building stock, settlement structure); at the same time, an important role is also played in the social life of the towns (e.g. the preservation of identity, shaping communities).
\end{abstract}

Key words: heritage products, tourism, Hajdu-Bihar county

\section{INTRODUCTION}

Heritage tourism can be considered as one of the fastest developing branches of tourism today, which intends to attract new visitors to settlements relying on historical

\footnotetext{
* Corresponding author
} 
assets. In order to raise the interest of tourists, it is necessary to develop attractions that differentiate the given destination from its competitors. At the same time, however, this requires a proactive approach by the local authorities: they need to assess the available resources, and then develop a suitable strategy relying on them in the interest of their utilisation. In the spirit of the above, the aim of the present paper is to examine from the above point of view the development documents of the most important settlements of a specific territorial unit in Hungary, Hajdú-Bihar county, which is located in the eastern part of the country. The questions we primarily seek to answer include how the heritage products appear in the specific documents concerned, and what changes can be observed over time between the documents prepared in different periods.

In the course of our analysis, we have devoted particular attention to exploring what extent local authorities consider elements of the built heritage as resources that can also be used in the framework of tourism. The paper can be fundamentally divided into four main parts. The first chapter explores the theoretical background of the topic concerned, which is followed by a discussion of the materials used and the research methodology applied. The third chapter includes the analysis of the documents concerned, while in the final chapter, a summary of the main findings can be found.

\section{THEORETICAL OVERVIEW}

In connection with the concept of heritage, researchers have formulated different opinions in the recent period (Jones et al., 2017). Initially, heritage decisively meant the built heritage; however, in recent decades, the meaning of the term became broader, and more emphasis has been placed on its close relationship with society, nature and culture. In this spirit, according to the phrasing of Prentice (1994), "heritage is an inheritance or legacy that is passed from one generation to the next", while Timothy and Boyd (2003) defined heritage as "those elements of past that society wishes to keep."

If we examine the possible uses of heritage, we can fundamentally differentiate between three areas. In the framework of use for societal purposes, certain elements of the historical past are used in the interest of strengthening the local identity and the shaping of communities, which is of outstanding significance in the everyday life of the given settlement (O'Neill, 2006; McDowell, 2008; Csurgó \& Szatmári, 2014; Ilieș et al., 2018, 2019; Indrie et al., 2019). When used for political purposes, the main effort is aimed at supporting an ideological current, notion or the activities of a political party with reference to the historical past, legitimizing various political values (Allen, 2010; Husz, 2014). The third - and actually best known - type is use for economic purposes, in the course of which, in the framework of heritage tourism, the effort is aimed at increasing the number of visitors to the given area, thereby increasing the revenues of society, as well as of the local and the central government (Timothy, 2011; Kozma \& Czimre, 2014; Bujdosó et al., 2015; Gozner et al., 2017; Ilieș et al., 2018; Lincu et al., 2018; Rapidah, 2018; Deac \& Gozner, 2019; Perez-Galvez et al., 2019;). This branch of tourism has a significant history (for example, in the $17^{\text {th }}$ and $18^{\text {th }}$ centuries, many English noblemen travelled to Continental Europe in order to view to classic Greek monuments, as well as the treasures of German, French, Italian and Dutch cities), but it only became widespread from the 1980s.

The utilization of heritage, as outlined above, however, also makes it necessary to manage it in a planned way: it is not enough only to think of preservation, and in this respect but we must adopt a dynamic approach and proactively manage the existing assets and create a well-marketable product (Fairclough, 2008; Smith, 2015; Janssen, 2017). The creation of the heritage product that satisfies the demands of the individual "target groups" is possible in several steps (Figure 1). The historic resources are composed of the 
wide and quite varied sum of the architectural relics, events, personalities and mythologies of the past which are in some way related to the given place. During the selection process, the elements of this set of sources are partly selected randomly (what remained and what are easily remembered) and partly - and to a greater extent consciously - what could be attractive for the potential consumers (thus, in the case of the conscious selection the really important factor is not the supply, but the demand side).

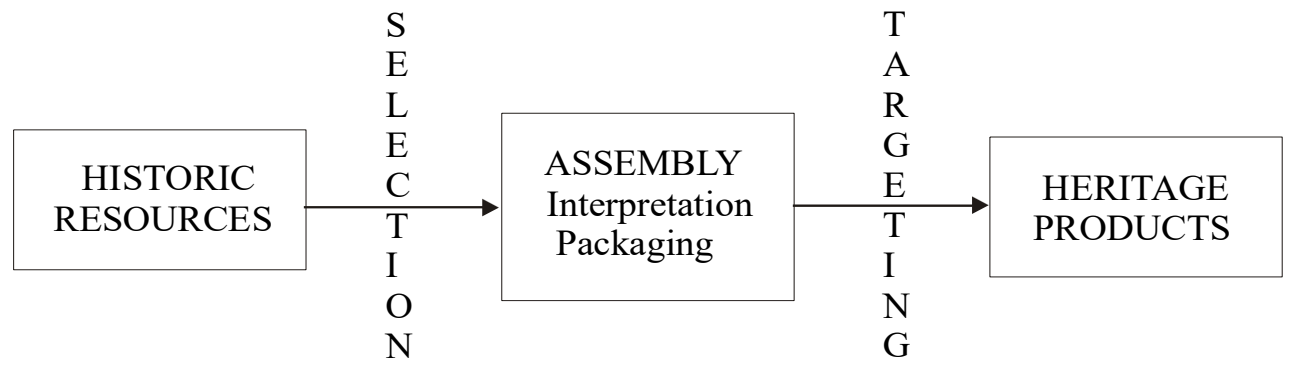

Figure 1. The model of the development of the heritage product

(Source: Tunbridge - Ashworth, 1996, p. 7)

The next stage is constituted by the presentation when the product to be sold is assembled from the selected sources and "packaged". In the course of this, two important things need to be taken into consideration. On the one hand, not the physical elements (like castle walls and buildings) are set into the centre but those hardly tangible emotions which are related to them including pride, nostalgia and fantasy. On the other hand, different heritage products may be produced from the same sources suiting the emerging demands. The last stage is the targeting when the developed product is forwarded to the consumers.

\section{MATERIALS AND METHODS}

In the course of this research project, we analysed Integrated Urban Development and Integrated Settlement Development Strategies. The documents of the former type fundamentally played an increasingly important role in the spirit of the Leipzig Charter on Sustainable European Cities adopted in 2007, in the second half of that decade (Barta, 2009), and in the 2017-2013 programming period only those cities had to prepare such a strategy that wanted to receive funding from the urban rehabilitation grants available under the Regional Operative Programmes. An Integrated Settlement Development Strategy is a medium-term development programme simultaneously serving the achievement of the environmental social and economic aims included in the settlement development concept (Section 2, point 12 of Act LXXVIII of 1997 on the Development and Protection of the Built Environment). In connection with the content of the given documents, there were some common elements (e.g. analysis of the situation, formulation of overall objective, medium-term thematic objectives, neighbourhood objectives, drawing up of anti-segregation programme). The provision of law applicable to the preparation of the latter (Government Decree 314/2012 (XI. 8.) on the settlement development concept, the integrated settlement development strategy and the settlement planning tools and on the specific settlement planning legislation), at the same time, contained much more detailed rules in many areas (e.g. it regulated more precisely the content of the so-called foundational examinations). In the selection of the materials, in addition to their easy accessibility (these documents had to be published by the local authorities on their websites), a role was also played by the fact they were 
prepared with more or less the same content, thereby providing an opportunity for comparisons in temporal and spatial terms. Both documents were available in case of 18 cities; therefore, the paper provides an examination of these (Figure 2).

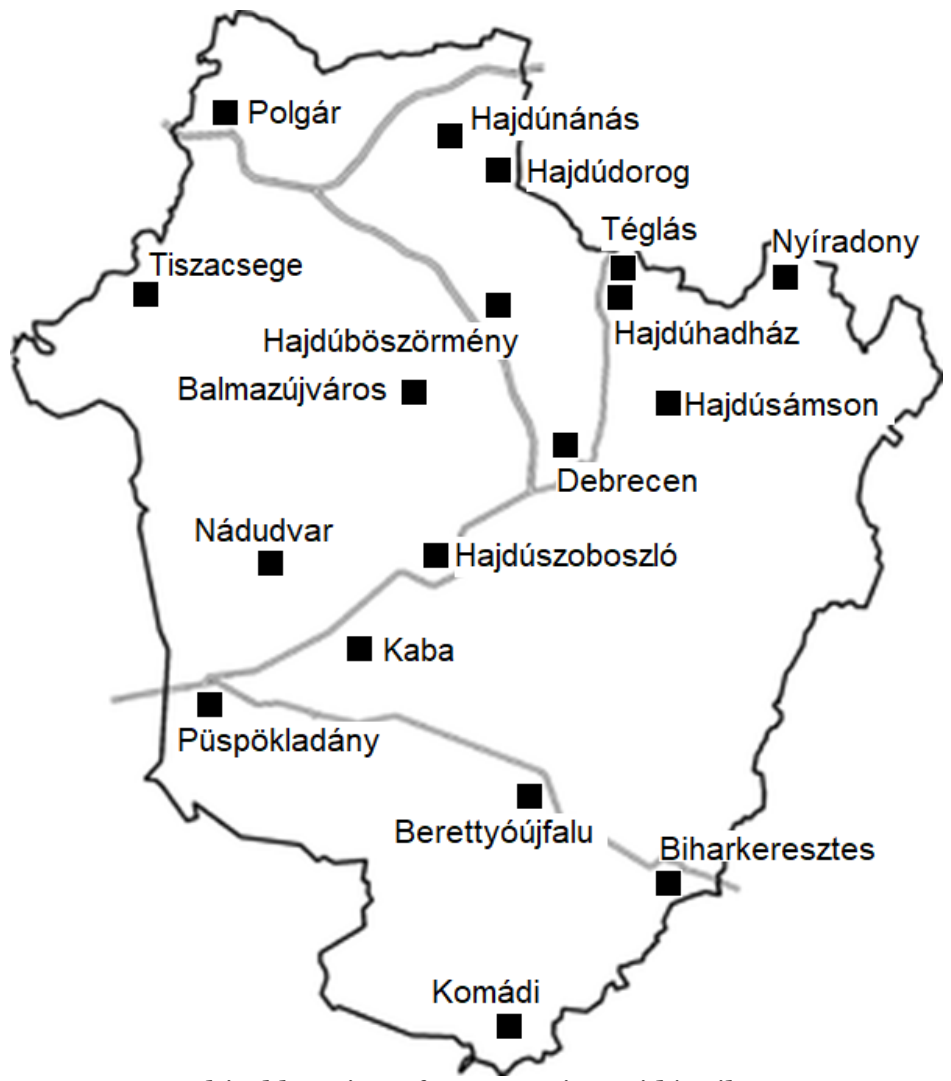

Figure 2. Geographical location of 18 towns in Hajdú-Bihar county examined

Table 1. The points assigned in the course of the analysis of the documents concerned

\begin{tabular}{|l|c|}
\hline \multicolumn{1}{|c|}{ Items examined } & points \\
\hline Situation-analysis chapter & \\
\hline - descriptive part: occurrence of the word "heritage" & 1 point/occurrence \\
\hline - descriptive part: occurrence of the word "heritage" in connection with tourism & 1,5 point/occurrence \\
\hline - SWOT-analysis: reference to heritage & 1 point/occurrence \\
\hline - SWOT-analysis: reference to heritage in connection with tourism & 1,5 point/occurrence \\
\hline Strategy chapter & 1 point \\
\hline - reference to heritage in the vision/overall objective & 1,5 point \\
\hline - reference to heritage in connection with tourism in the vision/overall objective & 0,5 point \\
\hline - reference to heritage in the description of the thematic objective & 1 point \\
\hline $\begin{array}{l}\text { - reference to heritage in connection with tourism in the description of } \\
\text { the thematic objective }\end{array}$ & \\
\hline
\end{tabular}

In the course of the analysis, we handled the chapters of the development documents dealing with the analysis/evaluation of the existing situation and those addressing the creation of strategy separately. In case of the former, we examined the 
appearance of the expression "heritage" in the textual part, while in the SWOT-analysis summarising the most important findings, it was already the examination of the occurrence of findings/conclusion related to the built environment that was usually in the focus. The chapter including the development strategy can be fundamentally divided into two parts. The plans of the settlements for the next 10 to 15 years are summarized by the vision/overall objective, the accomplishment of which is possible by way of the various thematic objectives/priorities. In the course of the analysis, we examined the elements referring to heritage on these two levels. In case of both the analysis of the situation and the strategy chapter, we have made an effort to quantify the occurrences related to heritage in the interest of ensuring that the changes over time can be traced well, and we also assigned separate points for elements related to tourism (Table 1).

\section{RESULTS}

Based on the examination of the chapters dealing with the analysis of the situation, a certain progress can be observed from the 2007-2013 to the 2014-2020 period (Table 2): the number of points given in the course of the quantification increased in every aspect of occurrence. At the same time, no significant increase in the number of documents can be observed, since in each of the periods there were 3 settlements in the development materials in which no reference to heritage occurred in any form. This fact refers to the fact that the local authorities concerned placed more emphasis on this aspect and included heritage in their completed strategies in a prioritized way. It is fortunate that the number of settlements recognizing the importance of heritage in tourism increased; at the same time, the proportion of these settlements did not reach 50\% either the description, or in the SWOT-analysis part.

Table 2. References to heritage in the analysis of the situation-analysis part of the settlement development documents prepared in the periods 2007-2013 and 2014-2020 (in brackets: the number of the occurrence of the given item: the number of documents in which the given item occurs) (Source: Integrated Urban Development Strategies and Integrated Settlement Development Strategies of towns)

\begin{tabular}{|l|c|c|}
\hline & $\begin{array}{c}\text { Integrated Urban } \\
\text { Development Strategy }\end{array}$ & $\begin{array}{c}\text { Integrated Settlement } \\
\text { Development Strategy }\end{array}$ \\
\hline Description - general aspect & $7.5(8)$ & $9.5(7)$ \\
\hline Description - connected to tourism & $3.0(2)$ & $4.5(3)$ \\
\hline SWOT-analysis - general aspect & $16.0(14)$ & $23.0(14)$ \\
\hline SWOT-analysis - connected to tourism & $7.0(5)$ & $10.0(7)$ \\
\hline Total score & 33.5 & 47.5 \\
\hline
\end{tabular}

See the method in Table 1

In terms of their form of appearance of heritage, we can fundamentally distinguish between three larger groups. The most important rule was played by buildings located in the central parts of the cities (from the 13 settlements mentioning heritage in each of the two periods, only one in each did not refer to such a building), and in connection with these, the development documents primarily considered the preservation of the image of the settlement as the most important task. Their special position is shown by the fact that six analyses of the situation mention concrete items (Balmazújváros - Semsey Castle, Téglás - Dégenfeld-Schomberg Castle, Hajdúböszörmény - Skansen, Hajdúdorog Greek Catholic Church, Biharkeresztes - Reformed Church, Hajdúsámson - Csiha mill) in the SWOT analysis as strengths of the given settlement (Figure 3).

The second place is occupied by the characteristic settlement structure (this occurs in the documents of four settlements), in the background of which we can find a unique 
feature of the region, the existence of the so-called "double infield" 1 settlement types (Figure 4). In the towns concerned, the population first settled in the centre (where smallsized plots were created due to fragmentation), and the economic activity (which primarily meant livestock farming) was concentrated on the outskirts of the settlement. At the same time, however, due to the increase of population, after a certain time the settlement parts further out on the periphery were also populated, the plots became more fragmented, and economic activity was pushed out to the boundary of the settlement. This process resulted in a characteristic internal structure (certain elements of which - such as a system of circular roads on the periphery and streets of radial structure - can even be observed today), which can be considered as typical in Eastern Hungary.

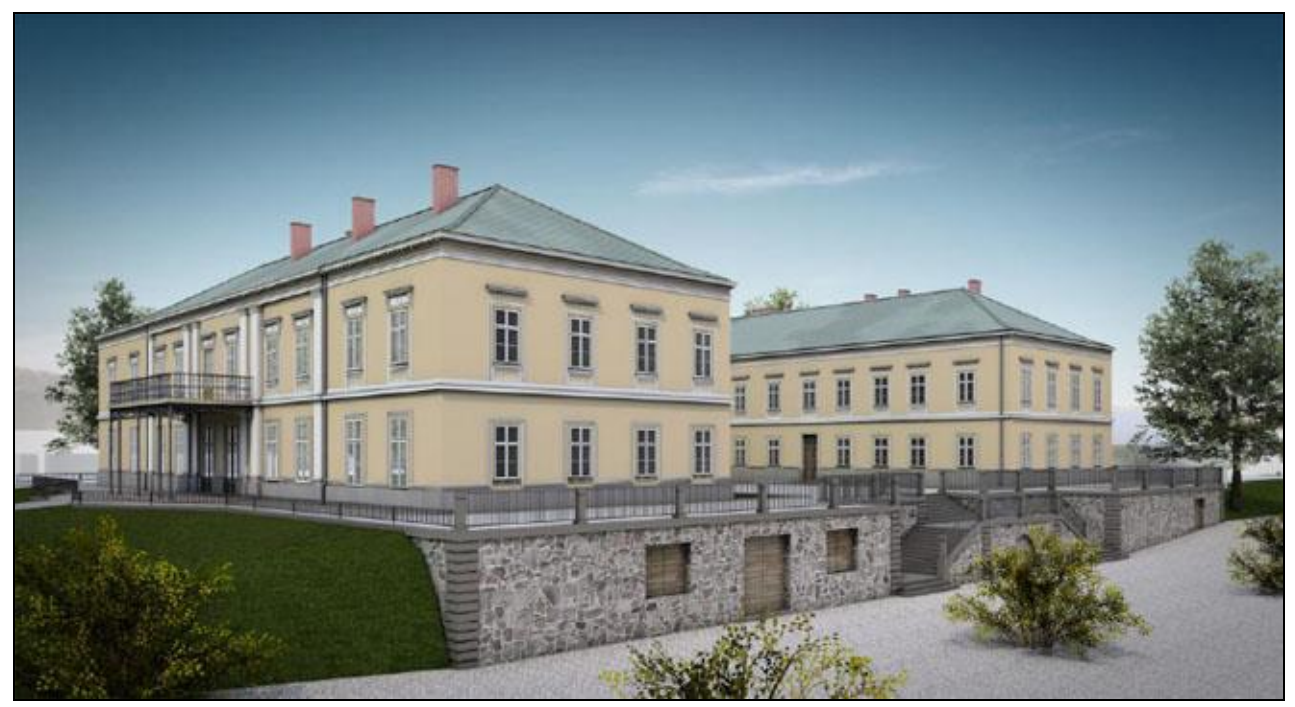

Figure 3. Dégenfeld-Schomburg Castle in Téglás (Source: www.degenfeldkastely.com)

The third important factor of cultural heritage was applied folk art, which was considered by a single settlement, Nádudvar, famous for its traditional craft of black pottery making (Figure 5), as a feature distinguishing it from its competitors.

In the course of the analysis of the part of the settlement development documents pertaining to strategy, as mentioned before, the vision/overall objective summarising the 10-to-15-year plan of the settlements was examined first. The analysis of the data reveals that heritage/tradition receives little attention on this level: from the 18 settlements examined, the Integrated Urban Development Strategies mentioned them 6 times, and the Integrated Settlement Development Strategies 8 times, while in connection with tourism they are only mentioned once in each group of strategies (Box 1). It can be regarded an interesting fact, however, that from these cases, there are only two settlements (Nádudvar and Hajdúböszörmény) where the given element of both strategies refers to the heritage. In our opinion, this can be explained by the fact that in case of the other settlements, heritage can be regarded as an endowment that can be less put to use, and therefore, it was not always included in the vision/overall objective, which can be considered as one of the most important messages of these documents.

\footnotetext{
${ }^{11}$ In Hungarian: "kétbeltelkes" (also referred to as "szálláskertes") settlements, where the farms and farm buildings were on strips of land surrounding the settlement proper, or even farther off
} 
The Relationship Between Heritage Products and Tourism in the Development Documents of Towns in Hajdú-Bihar County

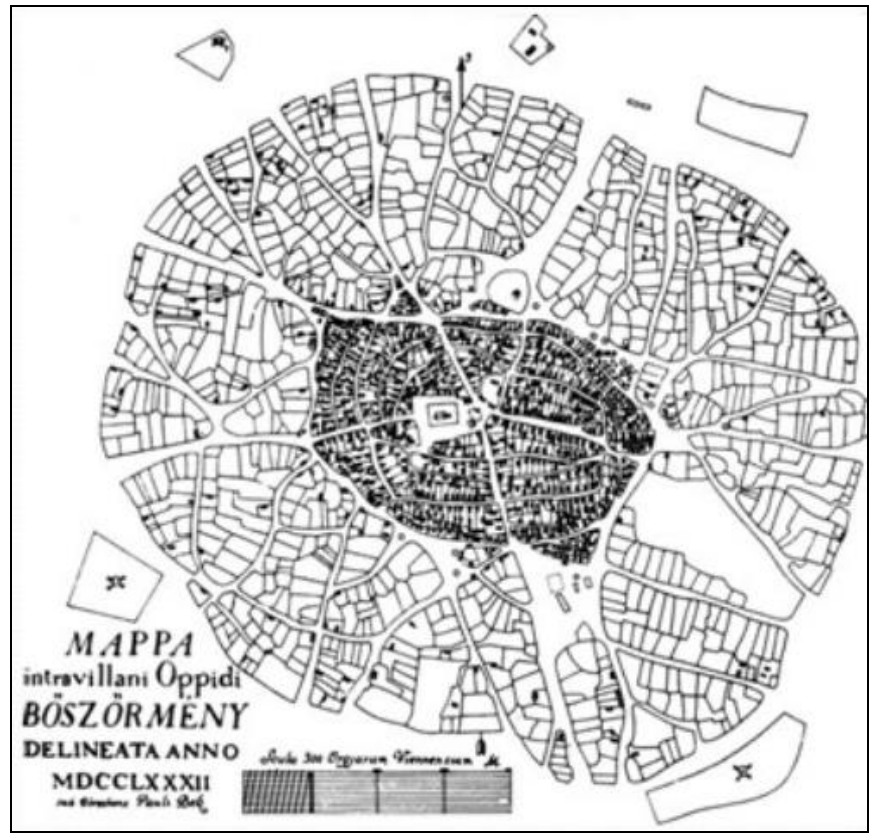

Figure 4. Urban structure of town Hajdúböszörmény in 1782 (Source: www.hajduboszormeny.hu)

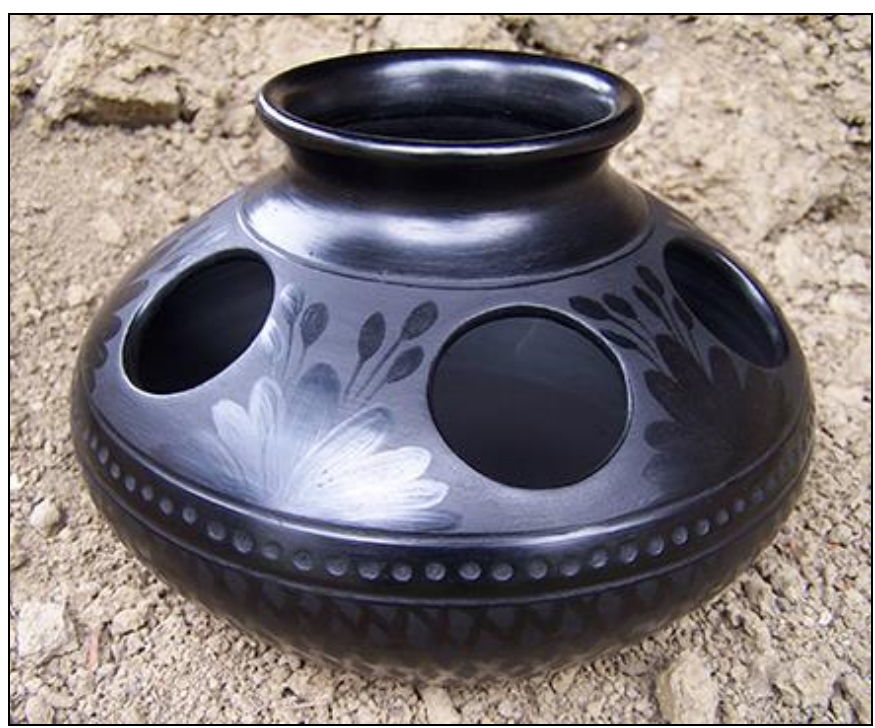

Figure 5. Black pottery made in Nádudvar (Source: www.feketekeramia.eu)

Tiszacsege is a small town of culture, preserving its traditions, relying on secure economic bases, which can ensure employment for the local population also in the long run. With the improvement of the quality of the natural and built environment, as well as the development of the services provided, it satisfies the expectations of both the local population and the visitors arriving there.

Box 1. Vision of town Tiszacsege (Source: Integrated Urban Development Strategy of town Tiszacsege) 
The second level of the examination concentrated on the thematic objectives (Box 2), in the framework of which the settlements defined the most important areas to which they wish to devote most attention in the next period of time (7-8 years).

T1. Creating the conditions of a competitive economy

T2. The development of the local cultural life and attractiveness for tourism

$\mathrm{T}_{3}$. The development of the settlement's environment and infrastructure, increasing energy efficiency

T4. The development of public services, the strengthen of the microregional role

T5. Encouraging municipal and regional cooperation, strengthening community consciousness, local identity and social inclusion in the interest of reducing the disadvantageous position

Box 2. Thematic objectives of town Kaba (Source: Integrated Settlement Development Strategy of town Kaba)

A general examination of this level of the strategies reveals that in their development strategies, settlements formulated quite different numbers of thematic objectives; the average, however, was similar in the two periods of planning (Table 3).

The local authorities fundamentally considered the development of tourism as an important task: this sector was included as a separate thematic objective in half of the development documents prepared. From the point of view of heritage, it can be considered as having an outstanding significance that, in contrast with the period between 2007 and 2013, when a link between tourism and heritage could only be observed in 5 cases, in the Integrated Settlement Development Strategies, heritage was already included in 9 out of 10 of the thematic objectives related to tourism as a possible force of attraction. One of the exceptions in both periods was Hajdúszoboszló, which is fundamentally due to the fact that the town, as the location of one of Central Europe's largest spa complexes, placed the main emphasis in the given thematic objective on the development of health, wellness and thermal spa tourism.

Table 3. The appearance of tourism and heritage in the thematic objectives (Source: Integrated Urban Development Strategies and Integrated Settlement Development Strategies of towns)

\begin{tabular}{|l|c|c|}
\hline & $\begin{array}{c}\text { Integrated Urban } \\
\text { Development Strategies }\end{array}$ & $\begin{array}{c}\text { Integrated Settlement } \\
\text { Development Strategies }\end{array}$ \\
\hline $\begin{array}{l}\text { minimum and maximum number of thematic } \\
\text { objectives }\end{array}$ & $3-10$ & $3-10$ \\
\hline average of thematic objectives & 6.4 & 6.4 \\
\hline $\begin{array}{l}\text { the appearance of tourism in the names of the } \\
\text { thematic objectives (times) }\end{array}$ & 9 & 10 \\
\hline $\begin{array}{l}- \text { of which, reference to heritage in the } \\
\text { description of the thematic objective }\end{array}$ & 5 & 9 \\
\hline
\end{tabular}

In light of the points put forward in the theoretical overview, the question arises in what other aspects the issue of heritage arises. An analysis of the titles of the thematic objectives allows us to set up 8 larger categories, which can be placed in the three groups on the basis of the values (Table 4). Standing out from among them is the built environment and its protection (Box 3), as well as tourism (Box 4), from among which the former can primarily be explained by way of the fact that heritage, in the thinking of the majority of people, means some kind of a historic monument/building. The second large group (culture and education, preservation of public identity - Box 5, the shaping of local community - Box 6) is fundamentally related to the human side of settlements, and it indicates the increasing importance of heritage in the shaping of the life of the settlement. 
The Relationship Between Heritage Products and Tourism

in the Development Documents of Towns in Hajdú-Bihar County

The third group is very complex; in addition to certain areas of comprehensive, summary nature (general infrastructure development, general economic development), settlement structures related to urban architecture can be found in this group.

Table 4. The appearance of heritage in the thematic objectives in terms of their titles (\%) (Source: Integrated Urban Development Strategies and Integrated Settlement Development Strategies of towns)

\begin{tabular}{|l|c|}
\hline title of the thematic objective & proportion of appearance \\
\hline the built environment and its protection & 27.1 \\
\hline the development of tourism & 23.7 \\
\hline serving culture and public education & 10.2 \\
\hline the preservation of local identity & 10.2 \\
\hline the shaping of the local community & 10.2 \\
\hline the protection/development of the settlement structure & 6,8 \\
\hline general infrastructure development & 6.8 \\
\hline general economic development & 6.8 \\
\hline
\end{tabular}

In the creation of the urban design, a criterion of special importance is taking the architectural traditions, as well as the opinions and expectations of the population into consideration, as is also the prior surveying of the investors expected to settle there.

Box 3. Connection between heritage and architecture in development strategy of town Téglás (Source: Integrated Settlement Development Strategy of town Téglás)

The protection of the cultural and natural heritage, facilitating its preservation and development are necessary, on the one hand, in the interest of local identity and pride; on the other hand, it also contributes to the urban image and may even serve, in certain cases, as tourist attractions.

Box 4. Connection between heritage and tourism in development strategy of Hajdúdorog (Source: Integrated Settlement Development Strategy of town Hajdúdorog)

The value-preserving utilisation of the traditions and character-bearing elements of settlements are also important components of the population's identity and the image of the settlement

Box 5. Connection between heritage and local identity in development strategy of Nyíradony (Source: Integrated Settlement Development Strategy of town Nyíradony)

Folk traditions and culture, as an important element carrying and expressing identity, should come to the foreground and contribute to the building of the community and the formation of self-awareness.

Box 6. Connection between heritage and shaping local community in development strategy of Püspökladány (Source: Integrated Settlement Development Strategy of town Püspökladány)

On the basis of the examination of the values of the individual settlements (Table 5), we can conclude that three settlements, Hajdúböszörmény, Nádudvar and Balmazújváros, can be placed in the first category, and these are the same towns that have the highest score in the area of tourism. Hajdúböszörmény is the second most populous settlement of the county, and until the administrative reform in the second half of the $19^{\text {th }}$ century, it served as the centre of the Hajdú district (it is still mentioned today as the capital of Hajdús), and is also the most representative example for "double infield" settlements (Figure 4), which are features explaining its special position. The prestigious position of Nádudvar can be traced back to its black pottery that is unique in the country (Figure 5), in case of Balmazújváros, the outstandingly valuable building stock justifies its favourable 
position, while the significant size of Debrecen is the reason behind its $4^{\text {th }}$ position. The settlements towards the end of the list (e.g. Kaba, Polgár, Nyíradony) are mainly the smaller ones in terms of populations (less than 10,000 inhabitants) and without a significant historic past (Hajdúsámson is located in the proximity of Debrecen, and its quick growth of population is due to large numbers of people moving there from the county seat), which is the reason for their low scores. At first sight, the position of Berettyóujfalu, a town with a population of approximately 15,000 people, may be surprising; however, the settlement only started its real development in the first half of the $20^{\text {th }}$ century (it became the seat of Bihar county after Oradea, formerly known as Nagyvárad, became a part of Romania as a result of the Trianon peace treaty, and this led to some major investments in the town), and it therefore its historical heritage is limited.

Table 5. The appearance of the topic of heritage in the development documents of the settlements (Source: Integrated Urban Development Strategies and Integrated Settlement Development Strategies of towns)

\begin{tabular}{|l|c|c|c|c|c|}
\hline & $\begin{array}{c}\text { situation- } \\
\text { analysis }\end{array}$ & $\begin{array}{c}\text { mission/general } \\
\text { aim }\end{array}$ & $\begin{array}{c}\text { thematic } \\
\text { objective }\end{array}$ & total & $\begin{array}{c}\text { tourism } \\
\text { in total }\end{array}$ \\
\hline Hajdúböszörmény & 12.5 & 2.0 & 2.0 & 16.5 & 6.5 \\
\hline Nádudvar & 9.0 & 2.0 & 5.0 & 16.0 & 8.0 \\
\hline Balmazújváros & 9.5 & 1.0 & 3.5 & 14.0 & 5.0 \\
\hline Debrecen & 6.0 & 1.0 & 3.0 & 10.0 & 3.5 \\
\hline Hajdúhadház & 5.0 & 1.5 & 1.5 & 8.0 & 1.5 \\
\hline Hajdúnánás & 6.5 & 0.0 & 1.5 & 8.0 & 0.0 \\
\hline Tiszacsege & 3.5 & 1.5 & 3.0 & 8.0 & 4.0 \\
\hline Püspökladány & 3.5 & 1.5 & 2.5 & 7.5 & 0.0 \\
\hline Hajdúszoboszló & 3.0 & 1.5 & 3.0 & 7.5 & 1.5 \\
\hline Hajdúdorog & 5.0 & 0.5 & 1.5 & 7.0 & 1.0 \\
\hline Biharkeresztes & 4.0 & 1.0 & 1.0 & 6.0 & 2.0 \\
\hline Komádi & 2.0 & 0.0 & 3.0 & 5.0 & 1.0 \\
\hline Kaba & 3.5 & 0.0 & 1.5 & 5.0 & 2.5 \\
\hline Téglás & 2.0 & 0.0 & 2.0 & 4.0 & 1.5 \\
\hline Polgár & 2.5 & 0.0 & 1.5 & 4.0 & 1.5 \\
\hline Hajdúsámson & 2.0 & 0.0 & 1.5 & 3.5 & 0.0 \\
\hline Berettyóújfalu & 0.0 & 0.0 & 3.0 & 3.0 & 2.0 \\
\hline Nyíradony & 1.0 & 0.0 & 1.5 & 2.5 & 1.0 \\
\hline See the metho
\end{tabular}

See the method in Table 1

\section{CONCLUSION}

The most important findings of the study could be summarised as follows. Based on a comparison of the Integrated Urban Development and Integrated Settlement Development Strategies, we can conclude that, as we move forward in time, increasing emphasis is given to this area in the development documents of the local authorities, and the above progress can be observed in both the chapter devoted to the analysis of the situation and in the strategic part of the materials. From among the values to be preserved in connection with heritage, the biggest emphasis is on the build environment; at the same time - due to the unique historical past of the towns - a very significant role is also given to the unique settlement structure.

Among the possible areas of the utilisation of heritage, the first place is occupied by the physical appearance of the settlements (building stock, settlement structure); at the same time, an important role is also played in the social life of the towns (e.g. the preservation of identity, shaping communities). The primary factors behind the difference in the importance attached to heritage are population size and the historical past. 
The Relationship Between Heritage Products and Tourism

in the Development Documents of Towns in Hajdú-Bihar County

\section{REFERENCES}

Allen, R. (2010). Heritage and nationalism. In Harrison, R. (ed) Understanding the politics of heritage. Manchester University Press in association With The Open University. pp. 217-230.

Barta, Gy. (2009). Integrált városfejlesztési stratégia: a városfejlesztés megújítása (Integrated Urban Development Strategy: the renewal of urban development). Tér és Társadalom, 23(3), pp. 1-12. (in Hungarian).

Bujdosó, Z., Baros, Z., Dávid, L., Baiburiev, R. \& Gyurkó, Á. (2015). Potential use of the coal and ore mining related industrial heritage for tourism purposes in the North Hungarian Region. Acta Geoturistica, 6(1), pp. 21-29.

Csurgó, B. \& Szatmári, A. (2014) Vidéki kultúra, helyi közösség, lokális identitás (Rural cultural, local community, local identity). Metszetek, 3(3), pp. 33-51. (in Hungarian).

Deac, L.A., Gozner, M. \& Sambou A. (2019). Ethnographic Museums in the Rural Areas of Crișana Region, Romania Keepers of Local Heritage, Tradition and Lifestyle. GeoJournal of Tourism and Geosites, 27(4), 1251-1260.

Fairclough, G. (2008). New heritage, an introductory essay - people, landscape and change. In Fairclough, G., Harrison, R., Shofield, J., Jameson, J. H. (eds.), The heritage reader, Routledge: Abingdon, pp. $297-312$.

Gozner, M., Tătar, C.F., Stupariu, M. \& Măduta, F.M. (2017). Nature, Photography and Tourism in BihorVlădeasa Mountains (Romania). GeoJournal of Tourism and Geosites, Year X, Volume 20, OradeaGdansk, Romania-Poland, Editura Universității din Oradea.

Husz, M. (2014). Az örökségkonstrukciók geopolitikai kerete (Geopolitical frame of heritage constructions). Földrajzi Közlemények, 138(1), pp. 64-73. (in Hungarian).

Ilies, D.C., Buhas, R., Ilies, M., Ilies, A., Gaceu, O., Pop, A.C., Marcu, F., Buhas, S.D., Gozner, M., \& Baias, S. (2018). Sport Activities and Leisure in Nature 2000 Protected Area - Red Valley, Romania. Journal of Environmental Protection and Ecology, 19, No 1, 367-372.

Ilieș, D. C., Oneț, A., Marcu, F.M., Gaceu, O.R., Timar, A., Baias, S., Ilieș, A., Herman, G.V. Costea, M., Țepelea, M., Josan, I. \& Wendt, J. (2018). Investigations regarding the air quality in the historic wooden church in Oradea city, Romania, in Environmental Engineering and Management Journal, Vol.17, no11, pp.2731-2739, http://www.eemj.icpm.tuiasi.ro/pdfs/accepted/204_294_Ilie\%C8\%99_17.pdf.

Ilieș, D.C., Oneț, A., Herman, G.V., Indrie, L., Ilieș, A., Burtă L., Gaceu, O., Marcu, F., Baias, S., Caciora, T., Marcu, A.P., Pavel, O.I., Costea, M., Ilieș, M., Wendt, J. \& Mihincău D. (2019), Exploring the indoor environment of heritage buildings and its role in the conservation of valuable objects, Environmental Engineering and Management Journal, December Vol. 18, No. 12, 2579-2586.

Indrie L., Ilieș, D. C., Oneț, A., Wendt, J. Ilieș, M., Timar, A., Ilieș, A., Baias, S. \& Herman, G.V. (2019). Indoor air quality of museums and conservation of textiles art works. Case study: Salacea Museum House, Romania, Industria textile, Vol. 70 No 1, pp 88-93.

Janssen, J., Luiten, E., Renes, H. \& Stegmeijer, E. (2017). Heritage as sector, factor and vector: conceptualizing the shifting relationship between heritage management and spatial planning. European Planning Studies, 25(9), pp. 1654-1672.

Jones, T., Mozaffari, A. \& Jasper, J. M. (2017). Heritage Contests: What Can We Learn from Social Movements?, Heritage \& Society, 10(1), pp. 1-25.

Kozma, G., \& Czimre, K. (2014). Role of historical elements in the slogans and logos used by Hungaroan places in toursim promotion. In Faracik, R. (ed) Enhancing competitiveness of V4 historic cities to develop toursim - Aspects of cultural heritage, Krakow - Debrecen, pp. 63-75.

Lincu, A., Ilieș, M., Ilieș, D.C., Herman, G.V., Baias, S., Gozner, M., Costea, M., \& Mihincău, D. (2018). Conservating the traditional cellars of Salacea, Bihor County, Romania. GeoJournal of Tourism and Geosites, 23(3), 748-758, https://doi.org/10.30892/gtg.23311-325

McDowell, S. (2008). Heritage, Memory and Identity. In Graham, B., Howard, P. (eds) The Ashgate research companion to heritage and identity. Ashgate: Aldershot, pp. 37-54.

O'Neill, M. (2006). Museums and Identity in Glasgow. International Journal of Heritage Studies, 12(1), pp. 29-48,

Melnychuk, A., \& Gnatiuk, O. (2019). Public perception of urban identity in post-Soviet city: the case of Vinnytsa, Ukraine. Hunqarian Geographical Bulletin, 68(1), pp. 37-50.

Pérez-Gálvez, J. C., López-Guzmán, T., Medina-Viruel, M. J. \& Torres-Naranjo, M. (2019). Heritage tourism in Ubeda Y Baeza (Spain). GeoJournal of Tourism and Geosites, 12(3), pp. 808-820.

Prentice, R. C. (1994). Heritage: a key sector of the new tourism. In Cooper, C. P., Lockwood, A. (eds) Progress in tourism, recreation and hospitality management vol 5., John Wiley: Chichester, pp. 309-324.

Rapidah, M. S., Mohamed, K. R., Ali, C. A., Leman, M. S. \& Saidin, M. (2018). The application of market appealrobusticity matrix: a case study of the arceological heritage of Lenggong Valley, Perak, Malaysia. GeoJournal of Tourism and Geosites, 11 (3), pp. 702-718.

Smith, J. (2015). Applying a cultural landscape approach to the urban context. In Taylor, K., St. Clair, A., Mitchell, N. (eds.) Conservering cultural landscapes. Challenges and new directions, Routledge: New York, pp. 182-197.

Timothy, D. J. (2011). Cultural heritaqe and tourism: an Introduction. Channel View Publication: Bristol Timothy, D. J. \& Boyd, S. W. (2003). Heritage tourism. Prentice Hall: Harlow.

Tunbridge, J. E. \& Ashworth, G. J. (1996). Dissonant Heritage: The Management of the Past as a Resource in Conflict. John Wiley \& Sons: Chichester.

Submitted:

22.11.2019
Revised:

21.02.2020
Accepted and published online 02.03.2020 